\title{
PENGEMBANGAN BAHAN AJAR TEMATIK INTEGRATIF PADA MATERI PENANGGULANGAN BENCANA ALAM SISWA KELAS V SDN TANJUNGREJO 4 MALANG
}

\author{
Alfiatus Safa'ah \\ Institut Agama Islam Syarifuddin Lumajang, Indonesia \\ Email : sherryalf3@gmail.com
}

\begin{abstract}
Frequent natural disasters in various areas of Indonesia always need responsive mitigation efforts. In education, this role can be realized by developing teaching materials of natural disaster mitigation.

The research was conducted at SDN Tanjungrejo 4 Malang with the research object of 39 fifth grade students. The purpose of this research and development of these materials include to know the process and to know the effectiveness of development of integrative thematic teaching materials in the content of natural disaster mitigation for the fifth grade students. This research is categorized in the Research and Development that was developed by Walter Dick and Lou Carey's develepomental models.

Feasibility of teaching materials can be seen from the validation results of the content's expert of $94.6 \%$, result validation of the design's expert is $95.6 \%$, the teacher of fifth grade students is $89.3 \%$, and the students of fifth grade is $86.7 \%$ which as a whole can be said to be a valid teaching materials and feasible to use.

The effectiveness of this teaching material can be seen from the increasing of the average of student's learning outcomes. Before the teaching materials were implemented, the average of student's learning was 58.27 and after using learning materials, the average score was increased to 80.02 .
\end{abstract}

Kata Kunci : Teaching Material, Integrative Thematic, Natural Disaster Mitigation

\section{Pendahuluan}

Letak negara Indonesia yang sangat strategis dan terdiri dari kurang lebih 13.677 pulau dan jumlah penduduk 237.641.326 jiwa1, sangat membutuhkan suatu informasi tentang keadaan alam yang lebih rinci sebagai pengetahuan. Hal ini mengundang para ilmuwan, lembaga sosial, pemerintah, bahkan praktisi pendidikan untuk terus mengembangkan

\footnotetext{
${ }^{1}$ www.bps.go.id
} 
segala hal yang berhubungan dengan kondisi alam di Indonesia agar terus dapat dipantau dan diperhatikan dari waktu ke waktu.

Mengenai kondisi alam yang terus berubah, banyak bencana yang ditimbulkan sehingga memakan korban yang tidak sedikit. Baik itu korban jiwa maupun harta benda. Dari pengalaman secara turun temurun ini dapat dikatakan bahwa ilmu tentang bencana alam haruslah disusun secara terstruktur, mulai dari pengetahuan sampai mitigasinya. Dari hal ini mulai diharapkan munculnya berbagai tindakan sosial yang pada akhirnya akan berefek pada tindakan kemanusiaan yang terus menerus sehingga manusia pun akan menjadi makhluk sosial yang berbudi.

Pendidikan bencana alam sendiri harus ditanamkan kepada siswa sejak dini. Jadi bukan hanya masyarakat dewasa saja yang tahu, tetapi peran pendidikan sejak dini juga sangat penting dalam hal ini. Bahkan jika diperlukan, peranan para ahli juga harus menjangkau jenjang ini untuk menyampaikan secara baik dan benar pengetahuan tentang bencana dan juga melakukan siaga bencana. Disadari ataupun tidak, pengetahuan yang dilaksanakan dengan praktek langsung tidak hanya menimbulkan kesan menarik bagi siswa, namun juga memberi memori ingatan jangka panjang. Kemasan pembelajaran yang menarik juga harus diperhatikan dalam melaksanakan kegiatan belajar di kelas.

Pengembangan bahan ajar pada materi bencana alam ini menjadi salah satu upaya dalam meningkatkan mutu pendidikan di sekolah. Dengan tematik integratif yang saat ini sedang gencar dicanangkan pada kurikulum terbaru, pemecahan masalah, studi kasus, bahkan studi praktek bahan ajar yang dikembangkan akan menjadi salah satu pilihan yang sesuai bagi murid dan pengajar untuk lebih mendalami materi dengan motivasi yang tinggi karena bentuknya yang berbeda dari yang sudah ada. Dengan berkolaborasi pada pendekatan tematik integratif, bahan ajar ini sangat praktis dan efektif digunakan dalam pembelajaran di 
kelas. Masalah pengajaran dan penerimaan informasi tentang materi akan terkesan lebih mudah dan menyenangkan dibanding dengan sebelumnya.

SDN Tanjungrejo 4 merupakan sekolah dasar negeri yang terletak di Sukun, Malang. Sekolah yang beralamat lengkap di Jl. Gempol no. 18 ini berlokasi cukup dekat dari lokasi longsor. Semakin dekat tempat penelitian dengan lokasi terjadinya peristiwa, maka pembelajaran yang diberikan akan lebih bermakna dibandingkan dengan meneliti di tempat yang jauh dari lokasi peristiwa terjadi. Efek yang ditimbulkan diharapkan juga akan semakin berkesan dengan adanya pembelajaran yang berhubungan dengan peristiwa dekat tempat tinggal para siswa. Siswa membutuhkan informasi mendalam tentang keadaan lingkungannya dan peristiwa yang terjadi pada lingkungannya. Bahan ajar ini membantu siswa menggali secara mendalam tentang lingkungan dan peristiwa yang terjadi di sekitar lingkungan siswa.

\section{Metode Penelitian}

Jenis penelitian yang dilakukan oleh peneliti adalah penelitian dan pengembangan. Metode penelitian dan pengembangan atau dalam bahasa Inggrisnya Research and Development adalah metode penelitian yang digunakan untuk menghasilkan produk tertentu, dan menguji keefektifan produk tersebut. ${ }^{2}$

Adapun model pengembangan yang dipakai adalah model pendekatan sistem yang dirancang dan dikembangkan oleh Dick and Carey dengan sepuluh langkah prosedural sebagai berikut: ${ }^{3}$ a) Analisis kebutuhan; b) Analisis pembelajaran; c) Analisis pebelajar dan konteks; d) Tujuan umum dan khusus; e) Mengembangkan instrumen; f) Mengembangkan strategi pembelajaran; g) Mengembangkan dan memilih

\footnotetext{
${ }^{2}$ Sugiyono, Metode Penelitian Kuantitatif, Kualitatif, dan $R \& D$, (Bandung: Alfabeta, 2011), hlm. 297.

3 Punaji Setyosari, Metode Penelitian Pendidikan dan Pengembangan, (Jakarta: Kencana, 2012), hlm. 223-226.
} 
bahan pembelajaran; h) Merancang dan melakukan evaluasi formatif; i) Melakukan revisi; j) Evaluasi sumatif.

Desain pelaksanaan penelitian meliputi proses membuat percobaan ataupun pengamatan serta memilih pengukuran-pengukuran variabel, memilih prosedur dan teknik sampling, alat-alat untuk mengumpulkan data kemudian membuat koding, editing, dan memproses data yang dikumpulkan. Dalam pelaksanaan penelitian termasuk juga proses analisis data serta membuat pelaporan. Instrumen yang digunakan dalam penelitian pengembangan ini adalah sebagai berikut:

1) Angket atau Kuesioner (Questionnaires)

2) Tes tertulis

3) Wawancara

4) Dokumentasi

5) Observasi

Untuk membuktikan signifikansi perbedaan antar aspek, perlu diuji secara statistik dengan t-test berkorelasi (related) dengan rumus sebagai berikut: 4

$$
t=\frac{\bar{d}}{\frac{S}{\sqrt{n}}}
$$

Dimana:

$\bar{d} \quad$ : Selisih antara $\mathrm{X}_{1}$ dan $\mathrm{X}_{2}$

$S \quad$ : Standar deviasi

$n \quad$ : Banyaknya sampel

Untuk menentukan presentase pada angket tanggapan dapat dipergunakan rumus sebagai berikut: ${ }^{5}$

${ }^{4}$ Sugiyono, Metode Penelitian Pendidikan: Pendekatan Kuantitatif, Kualitatif, dan $R \& D$, (Bandung: Alfabeta, 2015), hlm. 422.

${ }^{5}$ Suharsimi Arikunto, Dasar-Dasar Evaluasi Pendidikan, (Jakarta: Bumi Aksara, 2003), hlm. 313. 
$P=\frac{\sum x}{\sum x i}$

Keterangan:

P : Prosentase kelayakan

$\sum x \quad$ : Jumlah total skor jawaban validator (nilai nyata)

$\sum x i \quad$ : Jumlah total skor jawaban tertinggi (nilai harapan)

Dalam pemberian makna dan pengambilan keputusan untuk merevisi bahan ajar digunakan kualifikasi yang memiliki kriteria sebagai berikut: 6

Tabel 1. Kriteria Kualifikasi Penilaian

\begin{tabular}{|c|c|c|}
\hline Prosentase & Kriteria & Keterangan \\
\hline $80-100 \%$ & Valid & Tidak perlu revisi \\
\hline $60-79 \%$ & Cukup valid & Tidak perlu revisi \\
\hline $40-59 \%$ & Kurang valid & Revisi \\
\hline $0-39 \%$ & Tidak valid & Revisi \\
\hline
\end{tabular}

Setelah proses validasi dilakukan, apabila diperoleh hasil yang mencapai skor $75 \%$ atau lebih, maka produk pengembangan bahan ajar tematik integratif pada materi penanggulangan bencana alam yang disusun telah bisa digunakan dalam pembelajaran serta dapat dikembangkan lagi sebagai bentuk penyempurnaan bahan ajar.

\section{Hasil dan Pengembangan}

Pengembangan bahan ajar tematik integratif pada materi penanggulangan bencana alam ini dimaksudkan untuk memberi pengetahuan kepada siswa perihal cara-cara yang dilakukan ketika bencana alam datang terjadi sehingga siswa dapat dengan sigap menghadapinya. Dari hasil observasi lapangan yang telah dilaksanakan mengenai letak sekolah, peneliti melihat posisi sekolah yang cukup dekat

\section{${ }^{6}$ Ibid.}


dari lokasi tanah longsor yang belum lama terjadi di daerah lingkungan sekolah.

Dari hasil temuan di atas, maka dapat diasumsikan bahwa pengembangan dan perumusan bahan ajar tematik integratif pada penganggulangan bencana alam dibutuhkan untuk membantu siswa siaga terhadap bencana alam sekaligus membantu memahami pembelajaran tematik.

Bahan ajar tematik integratif pada materi penanggulangan bencana alam hasil penelitian dan pengembangan ini berupa buku siswa kelas $\mathrm{V}$ sekolah dasar yang mencakup materi semester I dan II serta mengacu pada Kurikulum 2013. Jumlah halaman pada bahan ajar ini ada 114 halaman yang terdiri dari sampul depan, sampul belakang, kata pengantar, daftar isi, petunjuk penggunaan buku, serta isi materi buku yang terdiri dari dua bab.

Bahasa yang digunakan dalam pembahasan bahan ajar dibuat dengan bahasa yang komunikatif, interaktif, dan mudah dipahami siswa. Tujuannya adalah agar siswa lebih mudah memahami materi yang diajarkan di dalam bahan ajar tematik integratif pada materi penanggulangan bencana alam. Bahasa yang dekat dengan kehidupan siswa lebih mudah diserap dan efektif diterapkan dalam pembelajaran.

Hasil validasi digunakan sebagai bahan revisi dan juga untuk mengetahui keefektifan bahan ajar dari berbagai aspek. Adapun rangkuman hasil validasi adalah sebagai berikut:

Tabel 2. Hasil Validasi Bahan Ajar

\begin{tabular}{|l|c|c|}
\hline \multicolumn{1}{|c|}{ Validator } & Hasil Validasi & Ket. \\
\hline Ahli Materi & $94,6 \%$ & Valid \\
\hline Ahli Desain & $95,6 \%$ & Valid \\
\hline Wali Kelas V & $89,3 \%$ & Valid \\
\hline Siswa Kelas V & $86 \%$ & Valid \\
\hline
\end{tabular}


Hasil belajar siswa didapatkan sebelum dan setelah melakukan pembelajaran dengan menggunakan bahan ajar tematik integratif pada materi penanggulangan bencana alam, peneliti menggunakan $t$-test guna mengetahui peningkatan hasil belajar siswa. Data nilai yang digunakan adalah ketika pelaksanaan Pre-Test dan Post-Test.

Adapun rumusan hipotesisnya/Ha nya adalah ada perbedaan yang signifikan pada prestasi belajar siswa kelas V SDN Tanjungrejo 4 Malang setelah menggunakan bahan ajar hasil pengembangan. Dari hasil penghitungan rata-rata hasil belajar diketahui bahwa nilai rata-rata pada Pre-Test adalah 58,2 yang dalam hal ini tidak memenuhi KKM pembelajaran. Sedangkan nilai rata-rata pada Post-Test atau setelah menggunakan bahan ajar adalah 80,02 yang artinya ada peningkatan ratarata nilai hasil belajar. Uji hipotesis dengan tingkat kemaknaan 5\% atau 0,05 adalah sebagai berikut:

Hipotesis yang digunakan yaitu:

1) $\mathrm{H}_{0}: \mu_{1}=\mu_{2}$ (Tidak terdapat perbedaan yang signifikan antara hasil belajar sebelum dan sesudah)

2) $\mathrm{H}_{0}: \mu_{1} \neq \mu_{2}$ (Terdapat perbedaan yang signifikan antara hasil belajar sebelum dan sesudah)

Titik kritis dalam penghitungan ini yaitu $a=5 \%$ atau $0,05 . d b=36$ Untuk hasil $t$-test adalah sebagai berikut: Standar Deviasi $=13,05 . T$-Test $=10,08$. Dalam uji signifikansi diketahui $t_{\text {tabel }}=2,028$.

Jadi, $t_{\text {hitung }}(10,08)>t_{\text {tabel }}(2,028)$. Hasilnya adalah signifikan, sehingga Ha diterima, Ho ditolak. Jadi, hipotesisnya adalah diterima karena $t_{\text {hitung }}>$ $t_{\text {tabel. }}$. Dengan kata lain, ada perbedaan yang signifikan pada hasil belajar siswa kelas V SDN Tanjungrejo 4 Malang pada saat sebelum dan setelah menggunakan bahan ajar tematik integratif pada materi penanggulangan bencana alam untuk kelas V sekolah dasar. 


\section{Pembahasan}

Dari hasil temuan yang didapatkan dari observasi lapangan di SDN Tanjungrejo 4 Malang mengenai perihal bahan ajar yang berhubungan dengan penanggulangan bencana alam sangatlah terbatas. Mengingat kondisi lingkungan sekolah yang perlu adanya penanganan pencegahan bencana alam, dan dalam hal ini diintegrasikan dalam bahan ajar, sehingga semua elemen masyarakat harus terus siaga dan waspada terhadap segala kemungkinan terjadinya bencana alam. Keterbatasan sarana untuk belajar tentang bagaimana cara menanggulangi bencana alam di kalangan siswa sekolah dasar mendorong peneliti untuk mengembangkan bahan ajar yang dapat digunakan sebagai penunjang kebutuhan belajar siswa mengenai materi bencana alam.

Bahan ajar yang dibuat oleh peneliti ini disusun secara sistematis, memotivasi peserta didik untuk belajar mandiri, memberikan konsep pada pemahaman peserta didik, menyediakan uji kompetensi untuk mengantisipasi kesukaran peserta didik dalam belajar, dan memberikan rangkuman pada setiap akhir bab. Oleh karena itu, peneliti menghasilkan bahan ajar dengan materi tentang penanggulangan bencana alam dengan komponen dari segi isi dan tampilan dalam bahan ajar yang menarik dan mudah digunakan. Di dalam isi bahan ajar ada tiga bagian, yaitu awal, isi, dan penutup. Dari segi tampilan dapat dilihat pada bentuk tulisan, warna dan gambar yang ada dalam bahan ajar.

Sesuai langkah pengembangan bahan ajar yang disarankan oleh Arif dan Napitupulu7, maka isi di dalam bahan ajar yang disusun harus memenuhi kelayakan dan kriteria yang telah ditetapkan. Diantaranya adalah penyesuaian Kompetensi Inti dan Kompetensi Dasar dengan materi dan kurikulum. Komponen isi dalam bahan ajar ada empat bagian, yaitu:

\footnotetext{
${ }^{7}$ Andi Prastowo, op cit., hlm. 408.
} 
a) Pada bagian pra pendahuluan terdiri atas halaman depan (cover), kata pengantar, tentang buku, dan daftar isi.

b) Pada bagian pendahuluan terdiri atas judul bab untuk mengetahui materi pembahasan yang akan dipelajari, peta konsep untuk mempermudah pemahaman materi pada peserta didik.

c) Pada bagian isi terdiri dari materi-materi tentang bencana alam dan penanggulangan bencana alam, review, aktivitas siswa, aktivitas kelompok, rangkuman sebagai ringkasan seluruh materi.

d) Pada bagian pelengkap buku berisi latihan soal yang digunakan untuk mengasah materi-materi yang telah dijelaskan serta untuk mengukur tingkat pemahaman peserta didik. Selanjutnya ada glosarium sebagai penjelasan dari kata-kata yang sulit dipahami oleh siswa pada materi yang ada dalam bahan ajar. Terakhir ada daftar pustaka sebagai rujukan yang diambil oleh peneliti dalam mengambangkan bahan ajar.

Beberapa hal mengenai desain layout bahan ajar yang perlu diperhatikan antara lain:

a) Ukuran kertas A4 (21 x 29,7 cm) dengan ketebalan 80 gram.

b) Huruf yang digunakan adalah Segoe UI dengan ukuran font 12 serta spasi 1,5 pt.

c) Warna yang digunakan dalam bahan ajar adalah $50 \%$ warna biru untuk laut, sungai, waduk, danau, gunung, dan lain-lain. 30\% untuk warna pepohonan, perkebunan, dataran. Serta 20\% untuk warna campuran sebagai tambahan warna agar terlihat lebih bervariasi.

Dalam pengembangannya, bahan ajar ini telah disempurnakan melalui tahap-tahap penelitian dan pengembangan. Diantaranya yaitu review ahli materi/isi, ahli desain, dan wali kelas V. Aspek yang dijadikan acuan untuk melakukan revisi adalah unsur materi, kesesuaian dengan kurikulum dan desain bahan ajar. Setelah proses validasi usai, tahap selanjutnya adalah revisi bahan ajar yang dilaksanakan sesuai dengan 
hasil validasi dan saran para ahli. Dari hasil validasi ahli isi/materi mendapatkan skor $94,6 \%$ yang artinya sudah valid, ahli desain produk mendapat skor 95,6\% yang artinya sudah valid, angket wali kelas mendapat skor $89,3 \%$ yang artinya sudah valid, dan angket siswa kelas $\mathrm{V}$ mendapat skor sebesar $86 \%$ yang artinya bahan ajar yang disusun sudah menarik bagi siswa. Dari sini bisa diambil kesimpulan dari keseluruhan hasil validasi bahwa bahan ajar telah layak digunakan dan efektif ketika digunakan sebagai acuan pembelajaran di kelas.

Hasil belajar adalah hasil yang diperoleh siswa setelah mengkuti suatu materi tertentu dari mata pelajaran yang berupa data kuantitatif maupun kualitatif. Untuk melihat hasil belajar dilakukan suatu penilaian terhadap siswa yang bertujuan untuk mengetahui apakah siswa telah menguasai suatu materi ataukah belum.

Uji coba bahan ajar yang dilakukan pada penelitian dan pengembangan ini ialah berupa kegiatan pembelajaran yang mana di dalamnya terdapat evaluasi. Dikarenakan keterbatasan waktu dan menyesuaikan keadaan lapangan, materi pembelajaran yang diuji cobakan pada penelitian dan pengembangan ini terdiri dari materi bencana alam gempa bumi dan penanggulangannya. Uji coba dilaksanakan selama 4 kali pertemuan dengan rincian:

1) Pertemuan I : Pelaksanaan Pre-Test

2) Pertemuan II : Pelaksanaan uji coba tahap I dan simulasi

3) Pertemuan III : Pelaksanaan uji coba tahap II dan evaluasi

4) Pertemuan IV : Pelaksanaan Post-Test dan pengisian angket siswa

Kualitas bahan ajar yang baik akan berpengaruh terhadap minat dan hasil belajar siswa. Apabila bahan ajar yang digunakan kurang sesuai dengan pemahaman dan kondisi siswa maka harus ada pengembangan yang mengarah kepada kemajuan. Hasil belajar yang diperoleh sebelum menggunakan bahan ajar tematik integratif pada materi penanggulangan bencana alam dengan KKM sebesar 65 adalah sebagai berikut. 
Tabel 3. Data Pre-Test dan Post-Test

\begin{tabular}{|l|c|l|c|}
\hline \multicolumn{2}{|c|}{ Data Pre-Test } & \multicolumn{2}{c|}{ Data Post-Test } \\
\hline Jumlah Siswa Tuntas & $\mathbf{1 4}$ & Jumlah Siswa Tuntas & 37 \\
\hline Jumlah Siswa Tidak Tuntas & $\mathbf{2 3}$ & $\begin{array}{l}\text { Jumlah Siswa Tidak } \\
\text { Tuntas }\end{array}$ & $\mathbf{0}$ \\
\hline Siswa Tidak Hadir & $\mathbf{2}$ & Siswa Tidak Hadir & $\mathbf{2}$ \\
\hline Jumlah Hasil Belajar & $\mathbf{2 1 5 6}$ & Jumlah Hasil Belajar & $\mathbf{2 . 9 6 1}$ \\
\hline Rata-rata & $\mathbf{5 8 . 2 7}$ & Rata-rata & $\mathbf{8 0 , 0 2}$ \\
\hline
\end{tabular}

Dari tabel di atas diketahui bahwa dari 39 siswa di kelas $V$, pada pretest ada 22 siswa dengan nilai di bawah KKM atau tidak tuntas. Jumlah ini lebih dari setengah banyaknya total siswa yang berada di kelas V. Hal tersebut menunjukkan kurangnya pengetahuan siswa terhadap materi penanggulangan bencana alam. Jika dilihat kembali pada hasil Pre-Test, maka dapat dikatakan bahwa siswa membutuhkan sarana untuk mengetahui kondisi lingkungan mereka, baik lingkungan sekolah maupun lingkungan rumah, agar terhindar dari bencana yang sewaktuwaktu terjadi.

Bahan ajar tematik integratif pada materi bencana alam ini terbukti efektif dalam meningkatkan hasil belajar siswa. Dalam implementasi pembelajarannya ketika dililhat dari segi efektifitas bagi semangat siswa, bahan ajar tematik integratif pada materi penanggulangan bencana alam ini sangat membantu siswa dalam menambah semangat belajarnya. Hal ini dapat dibuktikan dengan antusias siswa ketika mengikuti pembelajaran. Banyak siswa bertanya maupun menjawab pertanyaan secara aktif selama proses pembelajaran berlangsung.

Di samping antusias siswa, tolak ukur keefektifan bahan ajar tematik integratif pada materi penanggulangan bencana alam ini juga dapat 
dilihat dari rata-rata hasil belajar yang meningkat. Semula, ketika pelaksanaan Pre-Test yang hanya menggunakan metode ceramah dan minim bahan ajar yang mendukung, siswa mendapatkan rata-rata nilai sebesar 58,27. Setelah melaksanakan pembelajaran dengan menggunakan bahan ajar tematik integratif pada materi penanggulangan bencana alam, nilai rata-rata siswa meningkat hingga 80,02. Hal ini menunjukkan bahwa bahan ajar ini tidak hanya efektif dari segi penambah motivasi belajar siswa di kelas, tetapi juga efektif dalam meningkatkan hasil belajar siswa. Bagi guru juga efektif digunakan sebagai panduan mengajar karena mudahnya penggunaan bahan ajar.

Untuk mengetahui signifikansi peningkatan tersebut, peneliti menggunakan analasis hasil Pre-Test dan Post-Test dengan t-test agar terlihat jelas peningkatan efektifitas bahan ajar yang terdapat pada penggunaan bahan ajar. Dari hasil penghitungan diketahui thitung $(10,08)>$ $t_{\text {tabel }}(2,028)$. Sehingga ada perbedaan yang signifikan antara sebelum dan setelah menggunakan bahan ajar tematik integratif pada materi penanggulangan bencana alam pada kelas V. Artinya, bahan ajar tematik integratif pada materi penanggulangan bencana alam secara efektif meningkatkan hasil belajar.

\section{Saran}

\section{Saran Pemanfaatan}

1) Diharapkan guru dapat mengembangkan materi bahan ajar serta pendekatan pembelajaran yang digunakan sehingga kegiatan belajar menjadi lebih bermakna.

2) Penyertaan media dan bahan ajar lain yang mendukung terlaksananya pembelajaran secara efektif dan efisien patut dipertimbangkan untuk dihadirkan dalam proses belajar mengajar sebab hal itu akan membantu pengoptimalan penggunaan bahan ajar. 


\section{Saran Pengembangan}

1) Bahan ajar tematik integratif pada materi penanggulangan bencana alam yang saat ini hanya membahas materi penanggulangan bencana alam, nantinya bisa dikembangkan lagi pada materi-materi lain dengan pendekatan yang lebih bervariasi.

2) Pengembang lain atau guru yang ingin mengembangkan bahan ajar dapat meluaskan objek penelitian pengembangan pada kelas lain maupun jenjang pendidikan lain untuk mengetahui sejauh mana efektifitas bahan ajar tematik integratif pada materi penanggulangan bencana alam ini dapat diimplementasikan dalam pembelajaran.

Disarankan kepada para guru kelas yang ingin mengembangkan bahan ajar tematik integratif pada materi penanggulangan bencana alam untuk menyesuaikan dengan kondisi sekolah dan analisis pembelajaran siswa.

\section{Daftar Pustaka}

Ahmad, Yusuf al-Hajj. 2008. Seri Kemukjizatan al-Qur'an dan Sunnah: Kemukjizatan Bumi dalam al-Qur'an dan Sunnah. Yogyakarta: Sajadah_press.

Ali, Mohammad. 2009. Pendidikan Untuk Pembangunan Nasional. Jakarta: Grasindo.

Arifin, Zaenal. 2009. Evaluasi Pembelajaran. Bandung: Remaja Rosdakarya.

Arikunto, Suharsimi. 2003. Dasar-Dasar Evaluasi Pendidikan. Jakarta: Bumi Aksara.

Armstrong, Thomas. 2013. Kecerdalam Multipel di dalam Kelas Edisi Ketiga (Terj.). Jakarta: Indeks.

Belawati, Tian. 2003. Materi Pokok Pengembangan Buku Ajar Edisi Pertama. Jakarta: Universitas Terbuka.

Desmita. 2009. Psikologi Perkembangan. Bandung: Remaja Rosdakarya. 
Alfiatus Safa'ah

Dryden, Gordon, dan Vos, Jeannete. 2002. Revolusi Cara Belajar (The Learning Revolution): Belajar Akan Efektif Kalau Anda dalam Keadaan "Fun". Bagian I: Keajaiban Pikiran (Terj.). Bandung: Kaifa.

Hartono. 2011. Pendidikan Integratif. Purwokerto: STAIN Press.

http://bpbd.malangkota.go.id 